\title{
Residues of veterinary drugs in milk in Brazil
}

\author{
Stefani Faro de Novaes ${ }^{*}$ Lígia Lindner Schreiner $^{1}$ Isabella Pereira e Silva ${ }^{1}$ Robson Maia Franco ${ }^{2}$
}

${ }^{1}$ Gerência Geral de Alimentos, Agência Nacional de Vigilância Sanitária (ANVISA), 71070-674, Brasília, DF, Brasil. E-mail: stefani.novaes@anvisa.gov.br. *Corresponding author.

${ }^{2}$ Departamento de Tecnologia de Alimentos, Faculdade de Veterinária, Universidade Federal Fluminense (UFF), Niterói, RJ, Brasil.

\begin{abstract}
Veterinary drugs are used in dairy cattle management mainly for therapy and prophylaxis of diseases, which chemicals may leave residues in milk. Human exposure and the unintentional consumption of residues of drugs can lead to side effects and development of resistant bacteria, representing a considerable concern to consumer health. This paper presents the occurrence of residues of veterinary drugs in milk from 2009 to 2011 in Brazil, monitored by the Official Program for Analysis of Residues of Veterinary Drugs in Foods of Animal Origin. A total of 961 samples were collected in the retail and evaluated for the main $\beta$-lactams, tetracyclines, amphenicol, aminoglycosides, quinolones, sulfonamides and avermectins. Residues of veterinary drugs did not exceed maximum residue limit (MRL); although, there is a considerable use of critically/highly important antimicrobials and avermectins in dairy cows, especially quinolones and tetracyclines. Doxycycline (9\%) and abamectin (1.6\%) were detected, even though these substances are not intended to be used in milk producing animals for human consumption. Norfloxacin (15\%) was observed; although, there are no MRL established, consequently, no residue level should have been detected. No residues of streptomycin, chloramphenicol and $\beta$-lactams were confirmed. Milk in Brazil contains low levels of veterinary drugs so that toxicological risk regarding milk consumption could not be considered as a public health concern. However, due to the nature of the samples, which correspond to milk from several farms, it could occur a dilution effect. The absence of MRL established for norfloxacin prevents suitable interpretation of the findings and makes tough the control of these chemical residues in food. Detection of some antimicrobials and avermectins may be linked to extra-label use or noncompliance withdrawal periods suggesting that good veterinary practices are not being followed, since residues of unauthorized drugs have been detected.
\end{abstract}

Key words: maximum residue limit, milk monitoring, toxicological risk, veterinary drugs.

\section{Resíduos de medicamentos veterinários em leite no Brasil}

RESUMO: Medicamentos veterinários são utilizados no manejo do gado leiteiro para tratamento e profilaxia de doenças, podendo deixar resíduos no leite. A exposição humana e o consumo não intencional de resíduos de drogas podem causar efeitos adversos e desenvolvimento de bactérias resistentes, representando importante preocupação para saúde do consumidor. Neste estudo é apresentada a ocorrência de resíduos de medicamentos veterinários no leite de 2009 a 2011 no Brasil, monitorado pelo Programa Oficial de Análise de Resíduos de Medicamentos Veterinários em Alimentos de Origem Animal. Total de 961 amostras foram coletadas no comércio e avaliadas para os principais $\beta$-lactâmicos, tetraciclinas, anfenicol, aminoglicosídeos, quinolonas, sulfonamidas e avermectinas. Resíduos de medicamentos veterinários não excederam os LMR, embora exista uso considerável de antimicrobianos criticamente/altamente importantes e avermectinas em vacas leiteiras, especialmente quinolonas e tetraciclinas. Doxiciclina (1,9\%) e abamectina $(1,6 \%)$ foram detectadas, embora não se destinem ao uso em animais produtores de leite para consumo humano. Norfloxacino (15\%) foi observado, mesmo não havendo LMR estabelecido, consequentemente, não deveria ter sido detectado qualquer nível de resíduos. Não foram confirmados resíduos de estreptomicina, cloranfenicol e $\beta$-lactâmicos. Conclui-se que o leite no Brasil contém baixos níveis de resíduos de medicamentos veterinários, de forma que o risco toxicológico relativo ao seu consumo não deve ser considerado problema de saúde coletiva. Contudo, é importante ressaltar a natureza das amostras, que correspondem ao leite de diversas fazendas e o efeito de diluição pode ter ocorrido. A ausência de LMR estabelecido para a norfloxacino impede uma interpretação adequada dos resultados e dificulta o controle de resíduos químicos nos alimentos. A deteç̧ão de certos antimicrobianos e avermectinas pode estar associada ao uso "extra-label" ou ao desrespeito dos periodos de carência, sugerindo que Boas Práticas Veterinárias não estejam sendo seguidas, visto que resíduos de fármacos não autorizados foram detectados.

Palavras-chave: limite máximo de resíduo, monitoramento de leite, risco toxicológico, medicamentos veterinários.

\section{INTRODUCTION}

Enhancing productivity in animal husbandry often involves the use of physiologically, pharmacologically and toxicologically important substances. Today hundreds of substances are widely used as active principles in health products developed for the treatment of food producing animals. Therefore, many animals are exposed to chemicals that may leave residues in food (VRAGOVÍC et al., 
2011). Veterinary drugs are commonly used in dairy cattle management for disease therapy, especially in mastitis treatment, and parasite control. Improper administration by farmers and veterinarians without observing the withdrawal time for treated animals can result in residues in milk and milk products and can contribute to the development of antimicrobial resistance and the spread of resistant bacteria and determinants, including those with serious health concerns (FAO/WHO, 1993; JONES, 1999).

Human exposure and unintentional consumption of residues of drugs in milk can lead to several side effects, representing a considerable concern since there is a risk to consumer health. The main risks are exemplified by allergic reactions, regularly associated with $\beta$-lactams antibiotics; genotoxic and carcinogenic responses, often related to chloramphenicol, sulfamethazine, nitrofurans, malachite green and gentian violet; and the development of antibiotic resistant strains of bacteria, with possible transference of resistance to other susceptible microorganisms (COSTA, 2002; FAO/WHO, 2015). The presence of even traces of drug residues in raw milk may have not only toxicological but also technical issues since it can prevent the fermentation processes used in the manufacture of dairy products. By causing partial inhibition of lactic bacteria, this can affect the sensorial quality of milk products and these contaminants have been a matter widely considered by the dairy industry (TRONCO, 2003).

Due to the harmful effects that residues of veterinary drugs in food can cause in humans, there is a need for countries to establish surveillance systems. In Brazil, veterinary drug residue monitoring is enforced according to requirements set down in Resolution MERCOSUL/GMC/RES no.54/00, which was internalized by Resolution-RDC no.53/2012 (MISTÉRIO DA SAÚDE, 2012). In line with these requirements, the Brazilian Health Regulatory Agency (ANVISA), the government agency responsible for managing the information from official monitoring tests of milk marketed in Brazil, launched the Program for Analysis of Residues of Veterinary Drugs in Foods of Animal Origin (Pamvet). The aim of the program is to evaluate residues of veterinary drugs milk as it is one of the most consumed foods of animal origin, having an important role in vulnerable population groups, such as infants and elderly people (ANVISA, 2009). Previous results of Pamvet were reported by PACHECO-SILVA et al. (2014) and the reports are available on ANVISA website.

This paper presented the official occurrence of residues of veterinary drugs in milk in the 2009-
2011 period all over the country. This information is essential in order to broaden the discussion about that relevant issue and to recommend preventive measures in the whole productive chain, being subsidized by good practices of veterinary drugs in food producing animals. Results will contribute to the analysis of Brazilian progress in residues control during these years, improving analysis risk, in order to provide reliable data for the government, scientific community and industry.

\section{MATERIALS AND METHODS}

This study was conducted by the Brazilian Health Regulatory Agency in cooperation with State Health Bodies and Brazilian Public Health Laboratories. In 2009-2011 periods, 961 milk samples were evaluated from several trademarks, selected randomly and collected in retail, encompassing all five regions of the country. Milk samples were collected in its original packaging by local sanitary surveillance agents. The largest number of analyzes was Ultra High Temperature (UHT) milk n=470/49\%; followed by powdered milk $\mathrm{n}=275 / 29 \%$; and pasteurized milk $\mathrm{n}=216 / 22 \%$. Sampling plan took into consideration the average food consumption data per capita in Brazil, which presented UHT milk as the most consumed milk, and it is in accordance with Codex Alimentarius concerning the number of samples required to detect at least one non-compliant result with pre-defined probabilities in a population having known noncompliance prevalence. Non-compliant prevalence estimated was 1\% (FAO/WHO, 2009; IBGE, 2011).

In general, the substances chosen to be monitored in the program were those that can leave residues in food, causing trade issues and which may pose a potential risk to human health. Monitoring a large number of milk samples for the presence of residues usually requires low cost screening methods. Thereby, samples were analyzed by screening method, using SNAP $^{\circledR} \beta$-lactam ST (IDEXX Laboratories Inc., Westbrook, ME). A positive screening result meant that the sample was subjected to confirmatory analysis. Tetracyclines, doxycycline, chloramphenicol, quinolones, aminoglycosides, sulfonamides and avermectins were analyzed directly by confirmatory tests. Prior to analysis of the samples all analytical methods used had to be validated according to the Commission Decision 2002/657/CE procedures (EUROPEAN COMISSION, 2002). Screening and confirmatory methods for each analyze, methods performances and the maximum residue limit (MRL) used and its reference, are shown in table 1. 
Table 1 - Screening and confirmatory methods (limit of detection, LOD; limit of quantification, LOQ) of the substances studied in milk analysis performed by the Program for Analysis of Residues of Veterinary Drugs in Foods of Animal Origin and MRL.

\begin{tabular}{|c|c|c|c|c|}
\hline Substances & Screening & Confirmatory & MRL & Reference \\
\hline$\beta$-lactams & \multirow{14}{*}{$\begin{array}{l}\text { SNAP }^{\circledR} \\
\beta \text {-lactam } \\
\text { LOD: } \leq 4 \mu \mathrm{g} \mathrm{L}^{-1}\end{array}$} & LC-MS & - & - \\
\hline Amoxicillin & & LOD: $1.2 \mu \mathrm{g} \mathrm{L}^{-1} ; \mathrm{LOQ}: 3.9 \mu \mathrm{g} \mathrm{L}^{-1}$ & $4 \mu \mathrm{g} \mathrm{L}^{-1}$ & Codex \\
\hline Ampicillin & & LOD: $0.02 \mu \mathrm{g} \mathrm{L}^{-1}$; LOQ: $0.1 \mu \mathrm{g} \mathrm{L}^{-1}$ & $4 \mu \mathrm{g} \mathrm{L}^{-1}$ & EU \\
\hline Benzyl penicillin & & LOD: $0.3 \mu \mathrm{g} \mathrm{L}^{-1}$; LOQ: $0.8 \mu \mathrm{g} \mathrm{L}^{-1}$ & $4 \mu \mathrm{g} \mathrm{L}^{-1}$ & MERCOSUR \\
\hline Cloxacillin & & LOD: $0.05 \mu \mathrm{g} \mathrm{L}^{-1}$; LOQ: $0.2 \mu \mathrm{g} \mathrm{L}^{-1}$ & $30 \mu \mathrm{g} \mathrm{L}^{-1}$ & EU \\
\hline Dicloxacillin & & LOD: $0.05 \mu \mathrm{g} \mathrm{L}^{-1}$; LOQ: $0.2 \mu \mathrm{g} \mathrm{L}^{-1}$ & $30 \mu \mathrm{g} \mathrm{L}^{-1}$ & EU \\
\hline Nafciline & & LOD: $0.5 \mu \mathrm{g} \mathrm{L}^{-1} ; \mathrm{LOQ}: 1.6 \mu \mathrm{g} \mathrm{L}^{-1}$ & $30 \mu \mathrm{g} \mathrm{L}^{-1}$ & EU \\
\hline Oxacillin & & LOD: $0.03 \mu \mathrm{g} \mathrm{L}^{-1}$; LOQ: $0.1 \mu \mathrm{g} \mathrm{L}^{-1}$ & $60 \mu \mathrm{g} \mathrm{L}^{-1}$ & EU \\
\hline Cefapirin & & LOD: $0.6 \mu \mathrm{g} \mathrm{L}^{-1}$; LOQ: $1.9 \mu \mathrm{g} \mathrm{L}^{-1}$ & $50 \mu \mathrm{g} \mathrm{L}^{-1}$ & EU \\
\hline Cefazolin & & LOD: $0.1 \mu \mathrm{g} \mathrm{L}^{-1} ; \mathrm{LOQ}: 0.5 \mu \mathrm{g} \mathrm{L}^{-1}$ & $50 \mu \mathrm{g} \mathrm{L}^{-1}$ & EU \\
\hline Cefoperazone & & LOD: $0.1 \mu \mathrm{g} \mathrm{L}^{-1} ; \mathrm{LOQ}: 0.3 \mu \mathrm{g} \mathrm{L}^{-1}$ & $20 \mu \mathrm{g} \mathrm{L}^{-1}$ & EU \\
\hline Cefquinome & & LOD: $1.6 \mu \mathrm{g} \mathrm{L}^{-1} ; \mathrm{LOQ}: 5.4 \mu \mathrm{g} \mathrm{L}^{-1}$ & $100 \mu \mathrm{g} \mathrm{L}^{-1}$ & EU \\
\hline Cephalexin & & LOD: $0.1 \mu \mathrm{g} \mathrm{L}^{-1}$; LOQ: $0.3 \mu \mathrm{g} \mathrm{L}^{-1}$ & $20 \mu \mathrm{g} \mathrm{L}^{-1}$ & EU \\
\hline Cephalon & & LOD: $0.2 \mu \mathrm{g} \mathrm{L}^{-1} ; \mathrm{LOQ}: 0.5 \mu \mathrm{g} / \mathrm{L}^{-1}$ & - & EU \\
\hline Tetracyclines & - & HPLC-UV/Vis & $100 \mu \mathrm{g} \mathrm{L}^{-1 \mathrm{a}}$ & MERCOSUR \\
\hline Chlortetracycline & - & LOD: $0.4 \mu \mathrm{g} \mathrm{L}^{-1}$; LOQ: $1.5 \mu \mathrm{g} \mathrm{L}^{-1}$ & - & - \\
\hline Oxytetracycline & - & LOD: $0.4 \mu \mathrm{g} \mathrm{L}^{-1} ; \mathrm{LOQ}: 1.5 \mu \mathrm{g} \mathrm{L}^{-1}$ & - & - \\
\hline Tetracycline & - & LOD: $0.4 \mu \mathrm{g} \mathrm{L}^{-1} ; \mathrm{LOQ}: 1.5 \mu \mathrm{g} \mathrm{L}^{-1}$ & - & - \\
\hline Doxycycline & - & LOD: $0.4 \mu \mathrm{g} \mathrm{L}^{-1} ; \mathrm{LOQ}: 1.5 \mu \mathrm{g} \mathrm{L}^{-1}$ & + & EU \\
\hline Amphenicol & - & LC-MS & - & - \\
\hline Chloramphenicol & - & LOD: $0.3 \mu \mathrm{g} \mathrm{L}^{-1}$; LOQ: $0.8 \mu \mathrm{g} \mathrm{L}^{-1}$ & ++ & MERCOSUR \\
\hline Aminoglycosides & - & QqQ(LIT) LC-MS & & - \\
\hline Neomycin & - & LOD:7.5; LOQ: $25 \mu \mathrm{g} \mathrm{L}^{-1}$ & $500 \mu \mathrm{g} \mathrm{L}^{-1}$ & MERCOSUR \\
\hline Gentamicin & - & LOD:8.1; LOQ:27 $\mu \mathrm{g} \mathrm{L}^{-1}$ & $200 \mu \mathrm{g} \mathrm{L}^{-1}$ & Codex \\
\hline $\begin{array}{l}\text { Dihydrostreptomycin/ } \\
\text { Streptomycin }\end{array}$ & - & LOD:7.5; LOQ:25 $\mu \mathrm{g} \mathrm{L}^{-1}$ & $200 \mu \mathrm{g} \mathrm{L} \mathrm{L}^{-1 \mathrm{~b}}$ & MERCOSUR \\
\hline Quinolones & - & QqQ(LIT) LC-MS & - & - \\
\hline Enrofloxacin & - & LOD:1.5; LOQ:5.0 $\mu \mathrm{g} \mathrm{L}^{-1}$ & $200 \mu \mathrm{g} \mathrm{L}^{-1 \mathrm{c}}$ & EU \\
\hline Ciprofloxacin & - & LOD: $0.4 ;$ LOQ:1.5 $\mu \mathrm{g} \mathrm{L}^{-1}$ & - & - \\
\hline Norfloxacin & - & LOD: $0.4 ;$ LOQ: $1.5 \mu \mathrm{g} \mathrm{L}^{-1}$ & NE & - \\
\hline Sulfonamides & - & HPLC-FL (LOD; LOQ $\mu \mathrm{g} \mathrm{L}^{-1}$ ) & $100 \mu \mathrm{g} \mathrm{L}^{-1 \mathrm{~d}}$ & MERCOSUR \\
\hline Sulfathiazole & - & $0.08^{*} 0.37^{* *} ; 0.10^{*}, 0.33^{* *}$ & - & - \\
\hline Sulfamethazine & - & $0.12^{*}, 0.48^{* *} ; 0.24^{*}, 1.24^{* *}$ & - & - \\
\hline Sulfadimethoxine & - & $0.30^{*}, 1.1^{* *} ; 0.36^{*}, 1.6^{* *}$ & - & - \\
\hline Avermectins & - & HPLC-FL & - & - \\
\hline Abamectin & - & LOD: $0.6 \mu \mathrm{g} \mathrm{L}^{-1} ; \mathrm{LOQ}: 1.0 \mu \mathrm{g} \mathrm{L}^{-1}$ & + & Codex \\
\hline Doramectin & - & LOD: $0.6 \mu \mathrm{g} \mathrm{L}^{-1}$; LOQ: $1.0 \mu \mathrm{g} \mathrm{L}^{-1}$ & $15 \mu \mathrm{g} \mathrm{L}^{-1}$ & Codex \\
\hline Ivermectin & - & LOD: $0.6 \mu \mathrm{g} \mathrm{L}^{-1}$; LOQ: $1.0 \mu \mathrm{g} \mathrm{L}^{-1}$ & $10 \mu \mathrm{g} \mathrm{L}^{-1}$ & Codex \\
\hline
\end{tabular}

Liquid chromatography mass spectrometry (LC-MS); Triple quadrupole linear ion trap mass spectrometer (QqQ(LIT) LC-MS); Highperformance liquid chromatography with ultraviolet-visible detection (HPLC-UV/Vis); High-performance liquid chromatography with fluorescence detection (HPLC-FL); Not established (NE). * Powdered milk; ${ }^{* *}$ UHT and pasteurized milk. + This substance is not intended to be used in animals from which milk is produced for human consumption. ++ This substance is not authorized for use in food producing animals. ${ }^{\mathrm{a}} \mathrm{MRL}$ refers to the sum of chlortetracycline, oxytetracycline and tetracycline. ${ }^{\mathrm{b}} \mathrm{MRL}$ refers to the sum of dihydrostreptomycin and streptomycin. ${ }^{\mathrm{c}} \mathrm{MRL}$ refers to the sum of enrofloxacin and ciprofloxacin. ${ }^{\mathrm{d}} \mathrm{MRL}$ refers to the sum of sulfathiazole, sulfamethazine and sulfadimethoxine. 
For the results interpretation, the MRLs of veterinary drugs used as reference were those that Brazil has harmonized in the framework of MERCOSUR by Resolution GMC no.54/2000. For those veterinary drugs which MRLs have not been established in MERCOSUR, the limits recommended by Codex Alimentarius were considered, and, in the absence, those established by the European Union (EU). For those substances, which no MRLs have been established, no residue level should be detected. MRLs are stated in table 1 . To sum up, results were considered unsatisfactory when it was higher than the MRL or when it was higher than the LOD for those substances which no MRLs have been established or no residue is allowed.

\section{RESULTS AND DISCUSSION}

A total of 961 milk samples were evaluated, however only 690 samples were previously tested by screening methods, using SNAP $^{\circledR} \beta$-lactam ST (IDEXX Laboratories Inc., Westbrook, ME). Almost all samples presented negative screening results, but 3 milk samples (rate 0.3\%), 1 UHT milk and 2 pasteurized milk, yielded a positive screening result for residues of $\beta$-lactams. These samples were further evaluated in confirmatory test, resulting in levels below the LOD.

Similar study in Brazil reported 722 milk analyses in 2002/2003 with 8 positive samples (rate $1.1 \%$ ) for $\beta$-lactams screening test, but the results were not confirmed in confirmatory tests (PACHECO-SILVA et al., 2014). False-positive responses may happen and are usually a result of interaction with certain substances used for milk preservation or for sanitation of milking machinery. Despite the possibility of occurrence of false-positive, investigation of the utility of IDEXX Snap test devices (IDEXX Laboratories Inc., Westbrook, ME) as tools for detecting antibiotic residues in powdered milk products showed that samples yielded definitive results consistent with expectations, and there were no instances of false-positive or false-negative readings (KNEEBONE et al., 2010).

The residues of veterinary drug analyzed by confirmatory methods in milk samples are summarized in table 2. In general, the levels were lower than the maximum limits proposed, despite the quantification of low levels of residues and the detection of drugs that were not supposed to be found in milk.

Concerning residues of antibiotics in milk samples; although, below the MRL established, there is a considerable use of quinolones and tetracyclines in dairy cows as shown below. In this study, the quinolones residues in milk, evaluated by Pamvet in Brazil, were officially investigated for the first time. A total of $170(17 \%)$ milk samples yielded positive results (concentrations higher than LOQ) for enrofloxacin; 238 (25\%) for ciprofloxacin and $134(15 \%)$ for norfloxacin. Relating to tetracyclines, the residues of chlortetracycline were detected in 93 $(12 \%)$ milk samples, oxytetracycline in $231(31 \%)$ and tetracycline in $104(14 \%)$. Doxycycline was detected in $70(9 \%)$, even though this substance is not intended to be used in animals from which milk is produced for human consumption and no residues should be reported (EUROPEAN COMISSION, 2010). Previous studies ratified the large use of tetracyclines and quinolones, being, respectively, the third and sixth group of antimicrobials with the highest number of citations, mainly regarding oxytetracycline, applied in metritis treatment, retained placenta, respiratory diseases and hull infectious diseases (PONTES NETTO et al., 2005). The presence of tetracyclines residues was equally reported in about $10 \%$ of powdered milk analyzed in 2006/2007 in Brazil (PACHECO-SILVA et al., 2014). PRADO et al. (2015) also demonstrated the occurrence of tetracyclines, including doxycycline, in $3 \%$ of pasteurized milk and estimated the daily intake in $0.05 \mu \mathrm{g} \mathrm{kg}^{-1}$ in Brazil. According to the literature, this study is the first to officially evaluate and report the quinolones contamination in milk marketed in Brazil.

The WHO Advisory Group on Integrated Surveillance of Antimicrobial Resistance classifies quinolones into highest-priority critically important antimicrobials. Quinolones are known to select for quinolone-resistant Salmonella and Escherichia coli in animals. At the same time, quinolones are one of few available therapies for serious infections. Given the high incidence of human disease due to Salmonella and $E$. coli, the absolute number of serious cases is substantial. Similarly, tetracyclines is classified into highly important antimicrobials that should be administered in accordance with prudent use principles, as there is considerable concern regarding the resistance mechanisms against some bacteria and limited therapy for infections (WHO, 2013). Besides the issue about human health, great concern in trade market may happen when there are no residues limits established for these substances. Although norfloxacin was present in milk samples in this study, no MRL has been established, consequently, no residue level should be detected. Difficulties in setting limits based on available data have been a challenge for countries, especially to older compounds. Once there is no MRL for a substance, no residue should 
Table 2 - Residues of veterinary drug in milk samples analyzed by the Program for Analysis of Residues of Veterinary Drugs in Foods of Animal Origin in the 2009-2011 period in Brazil.

\begin{tabular}{|c|c|c|c|c|c|c|c|c|c|c|c|c|c|c|c|}
\hline \multirow[b]{2}{*}{ Analyte } & \multicolumn{5}{|c|}{----------------UHT milk--------------- } & \multicolumn{5}{|c|}{----------Pasteurized milk----------- } & \multicolumn{5}{|c|}{----------Powdered milk----------- } \\
\hline & $=$ & ิ) & 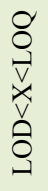 & 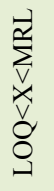 & $\underset{\wedge}{\nexists}$ & $=$ & $\underset{\mathrm{\theta}}{\mathrm{O}}$ & 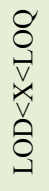 & 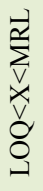 & $\underset{\wedge}{き}$ & $=$ & $\stackrel{\ominus}{\stackrel{\ominus}{\ominus}}$ & 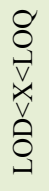 & 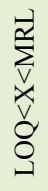 & $\underset{\wedge}{き}$ \\
\hline Chlortetracycline & 386 & 352 & 1 & 33 & - & 158 & 157 & - & 1 & - & 199 & 141 & - & 58 & - \\
\hline Oxytetracycline & 386 & 329 & 48 & 9 & - & 158 & 116 & 35 & 7 & - & 199 & 67 & 45 & 87 & - \\
\hline Tetracycline & 386 & 358 & 8 & 20 & - & 158 & 145 & 5 & 8 & - & 199 & 136 & 15 & 48 & - \\
\hline Doxycycline & 386 & 360 & 24 & 2 & - & 158 & 158 & - & - & - & 199 & 155 & 30 & 14 & - \\
\hline Chloramphenicol & 386 & 386 & - & - & - & 158 & 158 & - & - & - & 199 & - & - & - & - \\
\hline Neomycin & 470 & 453 & 17 & - & - & 216 & 196 & 19 & 1 & - & 275 & 227 & 47 & 1 & - \\
\hline Gentamicin & 470 & 466 & 4 & - & - & 216 & 215 & - & 1 & - & 275 & 275 & - & - & - \\
\hline Streptomycin & 470 & 470 & - & - & - & 216 & 216 & - & - & - & 275 & 275 & - & - & - \\
\hline Enrofloxacin & 470 & 407 & 52 & 11 & - & 216 & 201 & 14 & 1 & - & 275 & 183 & 55 & 37 & - \\
\hline Ciprofloxacin & 470 & 389 & 49 & 32 & - & 216 & 180 & 28 & 8 & - & 275 & 154 & 56 & 65 & - \\
\hline Norfloxacin & 470 & 428 & 27 & 15 & $\mathrm{NE}$ & 216 & 212 & 3 & 1 & $\mathrm{NE}$ & 275 & 187 & 42 & 46 & $\mathrm{NE}$ \\
\hline Sulfathiazole & 321 & 320 & - & 1 & - & 121 & 121 & - & - & - & 153 & 153 & - & - & - \\
\hline Sulfamethazine & 321 & 316 & - & 5 & - & 121 & 121 & - & - & - & 153 & 152 & - & 1 & - \\
\hline Sulfadimethoxine & 321 & 317 & - & 4 & - & 121 & 121 & - & - & - & 153 & 153 & - & - & - \\
\hline Abamectin & 336 & 331 & 5 & - & - & 120 & 116 & 4 & - & - & 178 & 177 & 1 & - & - \\
\hline Doramectin & 336 & 330 & 3 & 3 & - & 120 & 120 & - & - & - & 178 & 178 & - & - & - \\
\hline Ivermectin & 336 & 236 & 80 & 20 & - & 120 & 106 & 11 & 3 & - & 179 & 112 & 51 & 16 & - \\
\hline
\end{tabular}

Limit of detection (LOD); Limit of quantification (LOQ); Maximum Residue Limits (MRL); Number of samples (n); Not established (NE).

be present in foodstuff, its use and control became more difficult to manage. In the twenty-third session, the Codex Committee emphasized the challenges in finding ways to address the data needs to bring veterinary drugs to risk assessment or in finding ways to address the "risk" for pharmaceutical products already approved by national authorities, establishing MRL (CODEX ALIMENTARIUS, 2016).

Lower levels of neomycin (85/8.5\%), sulfonamides (11/1.8\%) and gentamicin (5/0.5\%) were detected. Gentamicin residues were evaluated for the first time in the program, as well. No residues of streptomycin and $\beta$-lactams were confirmed in milk samples. Previously, analysis of neomycin and $\beta$-lactams performed in Pamvet yielded positive results in less than $5 \%$ of the milk samples (PACHECO-SILVA et al., 2014). Although $\beta$-lactams and aminoglycosides, including neomycin, gentamicin and streptomycin, have a great use for the treatment of Gram-negative bacteria in mastitis, low residues levels might appear in the edible animal products due to extra-label use of veterinary drugs or noncompliance withdrawal periods (PONTES NETTO et al., 2005).

Comparing these results with other regulatory surveys, the findings of United States (US) also revealed a small number of overall confirmed positive drug residues, which means that concentration was above the tolerance or safe level or if the drug did not have a tolerance in milk and was above the confirmation of identity. Percent of positive samples, considering all drugs, in the targeted dairy farm population (farms with a previous tissue residue violation) was $1.15 \%$ while that in the non-targeted sampled dairy farm population (randomly selected dairy farms) was $0.42 \%$. Similarly, residues of drugs that are not approved for use in lactating dairy cattle were detected, which may also suggest the extra label use in US (FDA, 2015).

In addition, the products evaluated are highly diluted and; although, no product does not 
remain hazardous concentrations, somewhere in the production chain these levels may have been high. Brazil banned the use of $\beta$-lactams, tetracyclines, amphenicols, quinolones and sulfonamides as growth promoter, enhancing additives or as feed preservatives in 1998 by Ordinance no.193, updated by Normative Instruction no.26/2009.

In the present study, there were no unsatisfactory samples considering chloramphenicol concentration in milk. The absence of residue in the samples indicated that the producers are complying with the good veterinary practice. Chloramphenicol (CAP) is a broad-spectrum antibiotic previously used in veterinary medicine because of its broad range of activity and its low cost. Its use was forbidden in many countries, including Brazil, due to the toxicological effects reported in humans, such as aplastic anemia and carcinogenicity, although present in low levels of concentration. Thus, great attention is paid for residues detection of CAP in milk and milk products. Despite the prohibition, residues have been detected in previous studies in Brazil, indicating its sporadic illegal use or environmental contamination, confirming the need for continuous monitoring programs to protect human health (OLIVEIRA et al., 2007; PACHECO-SILVA et al., 2014).

Regarding avermectins, levels of the analytes in milk samples were also lower than MRL. Nevertheless, the results indicate that there is a substantial use of ivermectin in dairy cows, since 295 (46\%) milk samples had some level of residues detected/quantified; although, below the MRL. The presence of doramectin was detected in 6 UHT milk samples and the occurrence of abamectin in 10 (1.6\%) milk samples. Abamectin residues should not be reported in milk, as this substance is not intended to be used in animals from which milk is produced for human consumption (FAO/WHO, 2015). However, results from previous official veterinary drug monitoring programs showed that avermectins, mainly ivermectin, were the main compounds reported in milk samples and abamectin residues were reported in $2.80 \%$ and $7.25 \%$ of the UHT and powdered milk, respectively (PACHECO-SILVA et al., 2014). Administration of these drugs during the lactation period is not recommended, but their use seems to be common in some regions of Brazil. Without regard to this concern, abamectin is also used as a pesticide, and it can occur at low levels in milk of animals that consume plants treated with the active principle. In Brazil, abamectin has authorized use, among other vegetables, in citrus and cotton crops, which can transfer residues to milk due to the ingestion of citrus pulp and cottonseed used in animal feed (ANVISA, 2006). Therefore, the real source of milk contamination should be investigated in order to prevent abamectin residues in milk.

\section{CONCLUSION}

Residues of veterinary drugs in milk analyzed in Brazil did not exceeded MRL in any of the samples studied. Thus, this concern seems not to be a risk to human health and should not be considered an alarming situation. However, the detection and quantification of critically/highly important antimicrobials in milk samples should be highlighted and call attention to investigation whether the use is in accordance with prudent use principles, as there is considerable concern regarding the resistance mechanisms against some bacteria and limited therapy for infections. Furthermore, the absence of MRL established for norfloxacin prevents suitable interpretation of the findings and makes tough the control of these chemical residues in food.

Even though samples do not remain hazardous concentrations, the presence of low levels of residues of veterinary drugs may be linked to extra-label use or noncompliance withdrawal periods. Additionally, the products evaluated are highly diluted and somewhere in the production chain these levels may have been high. Concerning substances having other approved uses, as pesticides for instance, the real source of milk contamination should be studied in order to improve the dairy management and prevent residues in milk.

The results also suggested that the good veterinary practices are not being followed by all producers, since residues of unauthorized drugs have been detected. The illegal use, extra-label use, noncompliance withdrawal periods or the environmental contamination support the need for investigation and continuous monitoring programs to protect human health.

\section{ACKNOWLEDGEMENTS}

This work is supported by Brazilian Health Regulatory Agency.

\section{REFERENCES}

ANVISA. Relatório 2006-2007 Monitoramento de resíduos em leite exposto ao consumo ( $5^{\circ}$ e $6^{\mathbf{0}}$ anos de atividades), jun. 2009. Available from: $<$ http://portal.anvisa.gov.br/alimentos/publicacoes $>$. Accessed: Nov. 30, 2016. 
CODEX ALIMENTARIUS. Report of the twenty-third session of the Codex Committee on Residues of Veterinary Drugs in foods - REP17/RVDF. United States of America: Codex Alimentarius Commission, 2016. 39p.

COSTA, E.O. Uso de antimicrobianos na mastite. In: SPINOSA, H.S. et al. Farmacologia aplicada à medicina veterinária. Rio de Janeiro: Guanabara Koogan, 2002. p.442-455.

EUROPEAN COMISSION. Commission Decision 2002/657/EC of 14 august 2002 on implementing council directive 96/23/EC concerning the performance of analytical methods and the interpretation of results 2002/657/EC. Official Journal of European Union, L221, 8e36, 2002.

EUROPEAN COMISSION. Council Regulation 37/2010/EU of 22 December 2009 on pharmacologically active substances and their classification regarding maximum residue limits in foodstuffs of animal origin. Official Journal of European Union, L15, 72p. 2010.

FAO/WHO. Codex Alimentarius Commission. Glossary of terms and definitions (Residues of Veterinary Drugs in Foods). Switzerland: CAC/MISC 5-1993. 3p.

FAO/WHO. Codex Alimentarius Commission. Guidelines for the design and implementation of national regulatory food Safety assurance program associated with the use of veterinary drugs in Food producing animals. Italy: CAC/GL 71-2009. 42p.

FAO/WHO. Codex Alimentarius Commission. Maximum residue limits (MRLs) and risk management recommendations (RMRs) for residues of veterinary drugs in foods. Switzerland: CAC/MRL 2-2015. 41p.

FDA (FOOD AND DRUG ADMINISTRATION) Department of Health and Human Services. Milk drug residue sampling survey. United States of America, 2015. 25p.

IBGE (INSTITUTO BRASILEIRO DE GEOGRAFIA E ESTATÍSTICA). Pesquisa de Orçamentos Familiares 20082009: Análise do Consumo Alimentar Pessoal no Brasil. Rio de Janeiro: IBGE, 2011. 150p.
JONES, G.M. On-farm tests for drug residues in milk. Petersburg: Virginia State University, 1999. 6p.

KNEEBONE, J. et al. Short communication: rapid antibiotic screening tests detect antibiotic residues in powdered milk products. Journal of Dairy Science, v.93, n9, p.3961-3964, 2010.

MINISTÉRIO DA SAÚDE. Agência Nacional de Vigilância Sanitária. Resolução RDC $\mathrm{n}^{\circ} 53$, de 02 de outubro de 2012. Dispõe sobre o Regulamento Técnico MERCOSUL Metodologias Analíticas, Ingestão Diária Admissível e Limites Máximos de Resíduos para Medicamentos Veterinários em Alimentos de Origem Animal. Diário Oficial [da] União, Brasília, D.F, p. 47-48, Oct. 03, 2012. Seção 1.

OLIVEIRA, R.C. de et al. Occurrence of chloramphenicol in pasteurized milk commercialized in the state of Paraná. Acta Scientiarum. Health Science, v.29, n.1, p.911-914, 2007.

PACHECO-SILVA, E. et al. Veterinary drug residues in milk and eggs. Química Nova, v.37, n.1, p.111-122, 2014.

PRADO, C.K. et al. Oxytetracycline, tetracycline, chlortetracycline and doxycycline in pasteurized cow's milk commercialized in Brazil. Food Additives \& Contaminants: Part B Surveillance, v.8, n.2, p.81-4, 2015.

PONTES NETTO, D. et al. Survey on the main veterinary medicines use in dairy cattle in the state of Parana - Brazil. Acto Scientiarum. Animal Science, v.27, n.1, p.145-151, 2005.

TRONCO, V.M. Manual para inspeção da qualidade do leite. 2.ed. Santa Maria: UFSM, 2003. 208p.

VRAGOVÍC, N. et al. Risk assessment of streptomycin and tetracycline residues in meat and milk on Croatian market. Food and Chemical Toxicology, v.49, p.352-355, 2011.

WHO. Critically important antimicrobials for human medicine. 4.rev. Switzerland: WHO Library Cataloguing-in-Publication Data, 2013. 31p. 